\title{
En mann i 70-årene funnet forvirret på treningstur
}

\author{
En mann i 70-årene ble innlagt etter at han var blitt funnet i en grøft. Han \\ var forvirret og fikk gradvis nedsatt bevissthet. Pasienten hadde en syre- \\ base-forstyrrelse som det skulle vise seg vanskelig å finne årsaken til.
}

\begin{abstract}
Mannen i 70-årene hadde dratt ut på treningstur og ble funnet forvirret $i$ en grøft ved siden av sykkelen sin. Ambulansepersonellet beskrev ham som ustø og hjelptrengende ved forflytning. Det forelå ingen opplysninger om hva som hadde skjedd eller når pasienten sist var sett. På legevakten ble det ikke observert tegn til ytre skader, tungebitt, munnfråde, spontan vannavgang, fokalnevrologiske utfall eller kardiologiske symptomer. EKG ble tolket som mulig atrieflimmer. Blodtrykket var $140 / 80 \mathrm{~mm} \mathrm{Hg}$, blodsukkernivået 6,2 $\mathrm{mmol} / \mathrm{l}(4,0-6,0 \mathrm{mmol} / \mathrm{l})$ og $\mathrm{CRP}$ nivået $<5 \mathrm{mg} / \mathrm{l} /<5 \mathrm{mg} / \mathrm{ll}$.
\end{abstract}

Pasienten ble innlagt i sykehus fra legevakten med mistanke om cerebralt infarkt.

Ved innkomst var blodtrykket uendret på 140/80 mm Hg, pulsen var regelmessig med 51 slag per minutt, EKG viste sinusrytme og AV-blokk grad 1. Pasienten var afebril og ikke smertepåvirket. Han var desorientert for tid, sted og egne data, dessuten hadde han dårlig samarbeidsevne og en tendens til å gjenta seg selv. Det var også mistanke om impressiv afasi. Han hadde semidilaterte egale pupiller med normal lysreaksjon, ustø gange uten falltendens til noen bestemt side og indifferente plantarreflekser. Ved undersøkelse ble det funnet skrubbsår på høyre lår og ankelødemer bilateralt. I mottaket latet han for øvrig vannet tre ganger $i$ løpet av 30 minutter.

Basert på denne undersøkelsen hadde vakthavende lege fortsatt cerebralt infarkt som tentativ diagnose.

Konvensjonell CT caput og perfusjons-CT viste ingen tegn til ferskt hjerneinfarkt eller hjerneblødning. Blodprøver ved innkomst viste leukocytter $6,4 \cdot 10^{9} / \mathrm{l},\left(3,5-11,0 \cdot 10^{\circ} / \mathrm{l}\right)$, kalium 4,1 mmol/l (3,5-5,0 mmol/l), magnesium 1,02 mmol/l $(0,70-0,95 \mathrm{mmol} / \mathrm{l})$, kreatinkinase (CK) $405 \mathrm{U} / \mathrm{l}(40-280 \mathrm{U} / \mathrm{l})$ og negativ s-etanol. Pasienten ble innlagt i nevrologisk avdeling med telemetri for observasjon.

Vi var usikre på om den mistenkte impressive afasien var reell eller om symptomene skyldtes forvirring. Det var ellers ingen nevrologiske utfall, og ettersom CT caput var negativ, var det nå liten grunn til å mistenke hjerneinfarkt. Andre årsaker til akutt forvirring ble derfor vurdert. Han lå med telemetri med tanke på mulig kardial årsak, og ettersom han var bradykard med puls på $51 \mathrm{slag} /$ min, rekvirerte man S-TSH og S-T4 med tanke på hypotyreose.

Fra komparenter fikk vi opplyst at pasienten fra tidligere hadde hypotyreose, deklive ødemer bilateralt og symmetrisk nevrogent hørselstap og at han hadde hatt en episode med mulig bevissthetstap noen måneder tidligere. De opplyste også at han trente daglig og jevnlig deltok i løpekonkurranser. Siste konkurranse hadde funnet sted dagen før innleggelsen.

Ved akutt forvirring kan flere differensialdiagnoser overveies, blant annet forstyrrelser i væske- eller elektrolyttbalanse, infeksjoner, metabolske forstyrrelser, intoksikasjon, alkoholabstinens, epilepsi, hjerneslag, hypoksi og urinretensjon. Flere av disse ble imidlertid vurdert som mindre sannsynlige hos en meget aktiv mosjonist.

Den første natten hadde pasienten en timediurese på ca. $300 \mathrm{ml} / \mathrm{t}$. Deler av væsketapet ble erstattet av infusjon med Ringer-acetat $200 \mathrm{ml} / \mathrm{t}$. Det ble observert små rykninger i hendene og rundt munnen. På morgenen utviklet han dyp, snorkende respirasjon og ble gradvis vanskeligere å få kontakt med. Omtrent 12 timer etter innleggelsen slo sykepleierne stansalarm grunnet ufrie luftveier og oppkast. Pasienten ble overflyttet til intensivavdelingen og intubert.

På intensivavdelingen ble det tatt blodgass, nye blodprøver og urinprøve (tab 1). Blodgassundersøkelsen viste blant annet en uttalt metabolsk acidose med pH 7,01 (7,37-7,45). Det var samtidig uttalt hyperkloremi og lett økt aniongap.

Prøvene viste påfallende stor hyperkloremisk acidose, og mulige årsaker ble vurdert inngående. Den nedsatte cerebrale funksjonen med redusert bevissthet ble også vekt-

\author{
Magnus Salomonsen \\ sanouk05@gmail.com \\ Anestesiavdelingen \\ Randolf Hardersen \\ Nyreavdelingen \\ Medisinsk klinikk \\ Maria Carlsson \\ Nevrologisk avdeling \\ Nordlandssykehuset, Bodø

\section{Erik Waage Nielsen \\ Anestesiavdelingen Nordlandssykehuset, Bodø og Universitetet i Nordland og Universitetet i Troms $\varnothing$}

> Se kommentar side 2487 
Tabell 1 Prøvesvar et døgn etter innkomst

Prøvesvar Referanseområde

\section{Blodgass}

$\mathrm{pH}$

$\mathrm{aB}-p \mathrm{CO}_{2}(\mathrm{kPa})$

$\mathrm{p}-\mathrm{HCO}_{3}-(\mathrm{mmol} / \mathrm{l})$

2,2

\section{Blodprøver}

Natrium (mmol/l) 153

Kalium (mmol/l)

Klor (mmol/l)

Kreatinin $1 \mu \mathrm{mol} / \mathrm{l})$

7,01

2,2

4

5,6

127

136

Aniongap i serum (mmol)

Albumin $\left(g / l^{2}\right.$

Serum-osmolalitet (mmol/l J20)

Osmolalt gap (mmol)

\section{Urin}

$\mathrm{pH}$

Aniongap (mmol)

Urin-natrium (mmol/l)

Urin-klorid (mmol/l)

Urinstiks

Positiv for protein og blod
Urin-kalium (mmol/l)
$22-27$

$7,37-7,45$

$4,7-6,0$

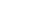

$178 \mu \mathrm{mol} / \mathrm{l}$ ved innkomst

2 Målt ved innkomst

lagt. De vanligste årsakene til metabolsk acidose med økt aniongap er ketoner eller laktat (1).

Ved danning av syrer vil syren (HA) danne $\mathrm{H}^{+}-$og $\mathrm{A}^{-}$-ioner $\left(\mathrm{HA} \leftrightarrow \mathrm{H}^{+}+\mathrm{A}^{-}\right)$. $\mathrm{H}^{+}$fanges opp av buffersystemer, mens $\mathrm{A}^{-}$forblir som et anion. $\mathrm{A}^{-}$fortrenger andre anioner og ses dermed som forhøyet aniongap (fig 1). Intoksikasjoner med etylenglykol, metanol og salisylater kan også gi et slikt bilde (1), i tillegg til soppforgiftning (2).

Hyperkloremi kan forklares med bikarbonattap, men vi fant ikke holdepunkter for tap av bikarbonat fra verken tarm, nyrer eller fistler mellom tarm og tilstøtende organer. Det var heller ikke infundert $\mathrm{NaCl}$, noe som på grunn av ufysiologisk mye klor kan gi hyperkloremisk acidose (3).

Vår pasient hadde en kombinert acidose, bestående av økt aniongap og hyperkloremi, noe som kan finne sted hvis det forekommer flere årsaker til metabolsk acidose samtidig (1).

Ettersom legene brukte laboratorieverdier fra ulike tidspunkter i sykdomsforløpet og beregnet osmolalitetsgapet med litt ulike formler, varierte det mellom $26 \mathrm{mmol} / \mathrm{log}$ $40 \mathrm{mmol} / \mathrm{l}$. Verdier over $25 \mathrm{mmol} / \mathrm{l}$ ses ved etanolinntak eller forgiftning med toksiske alkoholer som metanol og etylenglykol (4). Intoksikasjon med disse stoffene ble derfor vurdert, men grunnet kun lett forhøyet aniongap og uttalt hyperkloremi så vi det som mindre sannsynlig. Det passet heller ikke med bildet av en tilsynelatende velordnet mann som drev flere typer idrett aktivt.

Åtte timer etter overflytting var pasienten fortsatt ikke våken, men reagerte på smertestimuli med å rynke øyebrynene.
Behandlende leger vurderte nå på nytt om det var en cerebral årsak til symptomene og rekvirerte ny cerebral CT.

Ny CT-undersøkelse var uforandret. Pasienten var sirkulatorisk stabil og pustet selv gjennom oral endotrakeal tube tilkoblet en åpen slange med kontinuerlig mottrykk. Han var nå blitt oligurisk.

Isolerte blodprøver analysert på sentrallaboratoriet viste svakt stigende laktatver$\operatorname{dier~(3,7~mmol/l~-~4,6~mmol/l~-~5,7~mmol/l),~}$ og utover kvelden andre døgn på sykehuset kom det store mengder vandig oppkast med mørk farge, positiv på hemofec.

Hematemesen vakte mistanke om mulig sirkulasjonsforstyrrelser i mage eller tarm, ileus eller en mulig fisteldanning fra pancreas til tarm. En sirkulasjonsforstyrrelse kunne vært årsak til den kombinerte acidosen (5).

Pasienten fikk kirurgisk tilsyn for om tarmiskemi kunne ligge bak den høye laktatverdien. Verken klinisk undersøkelse eller CT abdomen avdekket noen tegn til dette. Gastroskopi viste øsofagitt grad B samt et lite hiatusbrokk, men ellers intet patologisk.

Videre ble det gjort spinalpunksjon, med funn av normalt celletall, normal glukose og totalprotein i spinalvæsken. Det ble rekvirert PCR av spinalvæsken for herpes simplex, varicella, cytomegalovirus og enterovirus samt analyse av borrelia.

Undersøkelsene med CT abdomen og gastroskopi ga ingen holdepunkter for sirkulasjonsforstyrrelser og laktatproduksjon i mage-tarm-kanalen, og det var ingen tegn til fisteldanning. Det var heller ingen tegn til laktatproduksjon fra iskemi i f.eks. underekstremiteter, som var velsirkulerte.

På grunn av pasientens vedvarende nedsatte bevissthet ble encefalitt og meningitt også vurdert i dette tidsrommet, men de foreløpige spinalvæskeundersøkelsene ga ingen holdepunkter for infeksjon.

Via nye komparentopplysninger fikk vi vite at pasienten hadde vært trett $i$ lengre tid. I pasientens hjem var det blant annet funnet paracet, tramadol og acetylsalisylsyre samt noen tomme plastflasker som det var usikkert hva hadde inneholdt.

Mulighetene for kronisk forgiftning fra disse medikamentene og flaskene ble vurdert, men funnet usannsynlig, gitt mannens hyppige deltakelse i konkurranseløp helt inntil dagen før det inntrufne. Akutt medikamentforgiftning ble vurdert som lite sannsynlig og alkoholforgiftning var usannsynlig, ettersom det ikke ble funnet etanol i 
innkomstprøvene. Det ble likevel bestilt analyse av en rekke medikamenter, inkludert paracet, og nytt s-etanol for å være sikker på at ingenting ble oversett. Pasienten ble vurdert av nevrolog, blant annet med tanke på potensielt reversibel encefalopati-syndrom (PRES) (6), metabolsk og paraneoplastisk encefalopati, men også disse diagnosene ble regnet som lite sannsynlige.

Andre døgn på intensivavdelingen var bevisstheten fortsatt nedsatt, med en Glascow Coma Scale-skår på 3. De første to døgnene ble det målt gradvis stigende laktat. 3. døgn steg laktatverdien fra $5,7 \mathrm{mmol} / \mathrm{l}$ til $29 \mathrm{mmol} / \mathrm{l}$. Laktatanalysen var gjort på en blodgassmaskin på intensivavdelingen. Kontrollmåling av laktatverdien på $29 \mathrm{mmol} / \mathrm{l}$ ble gjort på sentrallaboratoriet - kontroll av samme prøve viste da laktat på 9,2 mmol/l $10,6-1,9 \mathrm{mmol} / \mathrm{ll}$. Således var det en diskrepans på 19,8 mmol/ I mellom laktatanalysen på blodgassmaskin og analysen gjort ved sentrallaboratoriet.

Legene fant ingen god forklaring på denne diskrepansen, og det var fortsatt ikke holdepunkter for laktatproduksjon fra verken iskemisk tarm eller ekstremiteter.

Dopplerundersøkelse av halskar og transkranial dopplerundersøkelse ble gjort som ytterligere utredning for å avdekke en eventuell sentral årsak til den vedvarende bevissthetspåvirkningen, men var begge uten patologiske funn.

Tredje intensivdøgn kunne pasienten nikke på oppfordring, men var tiltakende motorisk urolig. Neste morgen fikk han generaliserte toniske kramper og cyanose. Krampene ble kupert med $5 \mathrm{mg}$ stesolid intravenøst.

Det ble tatt EEG, som viste langsom aktivitet over begge hemisfærer, men ingen tegn til epileptiform aktivitet. MR caput viste vasogent ødem i basalganglier og thalamus bilateralt, medialt temporalt bilateralt, svarende til hippocampus og parahippocampus, i mesencefalon og bakre del av pons samt i medulla oblongata. MR-angiografi av intracerebrale kar viste normale funn. Pasienten hadde kraftig forhøyet s-kortisol 11627 nmol/l (140-690 nmol/(l)) og gradvis stigende kreatininnivå og kreatinkinase (CK). CRP-nivået var økt til 223 $\mathrm{mg} / \mathrm{l}(<5 \mathrm{mg} / \mathrm{ll}$.

Leverprøver og ammoniakknivå var normale. Karbamid- og uratnivået var forhøyet. Pasienten hadde også hypernatremi linntil $152 \mathrm{mmol} / \mathrm{ll}$ og hyperkalemi (inntil 6,0 $\mathrm{mmol} / \mathrm{ll}$ samt forhøyet nivå av klorid og fosfat. Det forelå nå negative prøvesvar på paracetamol, etanol og litium, som bekreftet fravær av intoksikasjon med disse, men ennå ikke prøvesvar på salisylatspeil. Vi konfererte med Giftinformasjonen med tanke på forgiftning, men en rekke agenser var alle- rede utelukket og vi kom ikke frem til annet sannsynlig toksisk agens.

I beskrivelsen av MR-funnene ble flere differensialdiagnoser nevnt som aktuelle, blant annet pontin og ekstrapontin myelinolyse, Behçets sykdom, encefalitt, paramalignt syndrom og hypoglykemi. Det ble også vurdert om MR-funnene kunne passe med etylenglykolforgiftning (7).

Det ble startet dialysebehandling med kontinuerlig venovenøs hemodiafiltrasjon grunnet oligurisk nyresvikt av ukjent årsak og elektrolyttforstyrrelser. Samtidig ble CT thorax rekvirert til neste dag med tanke på malignitet, men heller ikke denne unders $\emptyset$ kelsen avdekket noe patologisk. Legeteamet rundt pasienten hadde fortsatt ingen sikker diagnose som forklarte symptomer og funn.

Fjerde intensivdøgn utviklet pasienten blikkdeviasjon nedad. Pupillene var små og reagerte på lys. Ved kraftig smertestimuli reagerte han med grimaser og løftet høyre overekstremitet, hvor han hadde myoklonier. Glascow Coma Scale-skåren var nå 6. Oligurien vedvarte, men med makroskopisk hematuri. Urinprøve tatt første døgn på intensivavdelingen ble først nå mikroskopert, etter fire døgn. Det ble funnet oksalatliknende krystaller, noe man blant annet kan finne ved etylenglykolforgiftning, uten at det er diagnostisk.

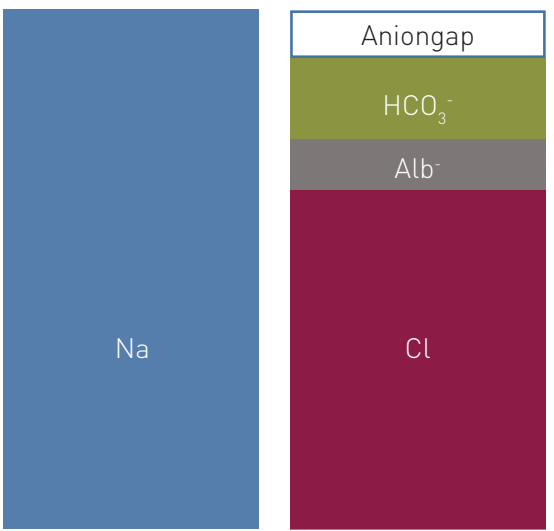

Figur 1 Forenklet Gamble-diagram

På dette tidspunktet opplyste en laboratorielege at blodgassapparatene våre kunne måle falskt forhøyet laktatnivå hvis det samtidig forelå glykolsyre eller xylitol i blodet. Samtidig kunne komparenter fortelle at pasienten ofte tok med seg tomflasker, og at det ikke var usannsynlig at han kunne ha drukket innholdet $\mathrm{i}$ en slik flaske han kunne ha funnet langs veien. Vi konfererte på nytt med Giftinformasjonssentralen. Ut fra osmolalt gap, aniongap og MR-funn samt diskrepansen eller gapet i laktataverdi mellom blodgassanalysene og serumanalysene på fluoridglass ble forgiftning med etylenglykol nå vurdert som mest sannsynlige årsak $(4,8,9)$. Det ble

\section{Laktat (mmol/l) Laktatmåling intensivavdelingen - Laktatmåling sentrallaboriatoriet}

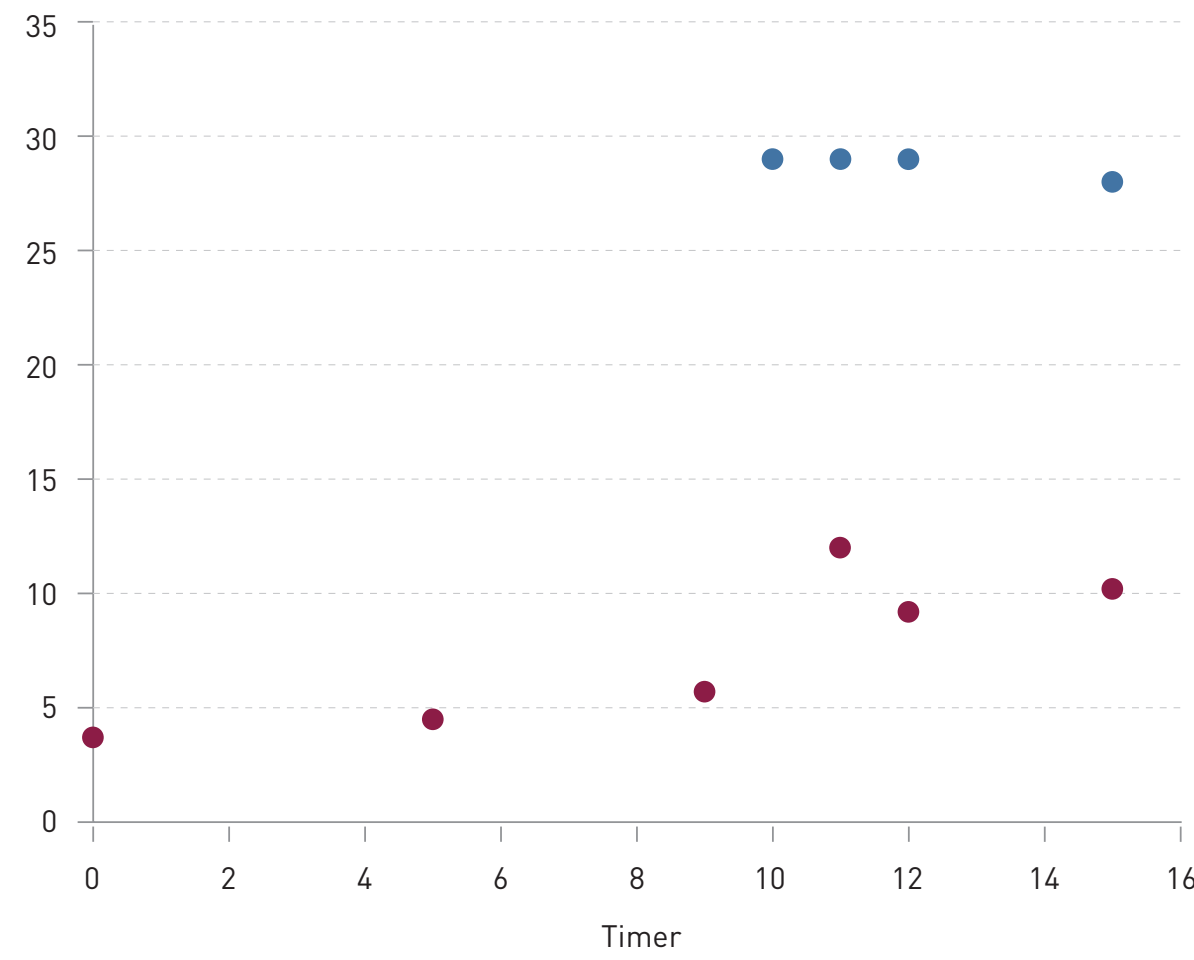

Figur 2 Forskjellen i måleverdier mellom intensivavdelingens og sentrallaboratoriets analyser 3. døgn etter innkomst 
etterrekvirert undersøkelse av etylenglykol i blodprøvene fra innkomsten. Det var imidlertid gått såpass lang tid siden da at man måtte anta at all etylenglykol ville være omdannet og at det var for sent å innsette fomepizol som antidot for å hemme alkoholdehydrogenasen (10-12).

Sjette intensivdøgn bekreftet laboratoriet ved regionsykehuset at prøven fra innkomstdagen var positiv for etylenglykol. Pasienten ble utskrevet fra sykehuset etter over en måneds behandling. Han er i dag hjemmeboende, uten dialysebehov, med et kreatininnivå på ca. $130 \mu \mathrm{mol} / \mathrm{l}(60-105 \mu \mathrm{mol} / \mathrm{l})$, men i noe redusert fysisk form.

\section{Diskusjon}

Både aksidentiell og villet intoksikasjon med etylenglykol forekommer med jevne mellomrom i norske sykehus. Doser under $0,5 \mathrm{ml} / \mathrm{kg}$ gir moderat til alvorlig forgiftning og krever sykehusinnleggelse (9). Doser over $0,5 \mathrm{ml} / \mathrm{kg}$ kan ubehandlet føre til døden (9). Symptomer, kliniske tegn og biokjemiske markører endrer seg i forskjellige stadier av metabolismen til etylenglykol, og det kan gjøre diagnosen vanskelig å stille. Det gjelder særlig når forgiftningen er aksidentell og helt uventet, som i vårt tilfelle.

Ubehandlet forgiftning kan gi økende metabolsk acidose, nyrepåvirkning, desorientering og redusert bevissthet, sirkulasjonssvikt og lungekomplikasjoner (lungeødem, akutt lungesviktsyndrom (ARDS)) (9). Siden vår pasient ikke fikk tidlig behandling med fomepizol og heller ikke dialyse før 3. døgn, gjennomgikk han trolig et slikt fulminant forløp med etylenglykolintoksikasjon.

Det kliniske forløpet kan deles i tre stadier (9). Først ses ofte ruseffekten, men alvorlig forgiftning utvikles selv om initiale symptomer er lite fremtredende. Det ses forhøyet osmolalitetsgap, og verdier over $25 \mathrm{mmol} / 1$ uten annen forklaring indikerer inntak av metanol eller etylenglykol (4).

I andre stadium omdannes etylenglykol til toksiske syrer, og dermed minker osmolalitetsgapet. Parallelt utvikles en økende metabolsk acidose med økt aniongap. Det kan utvikles hypokalsemi, kalsiumoksalatkrystaller i urinen og kramper, som hos vår pasient $(4,9)$. Hos ham ble det ikke tatt blodgass eller serum-osmolalitet ved innkomst, og vi vet derfor ikke om det allerede da var toksiske syrer til stede.

I tredje stadium finner man økende metabolsk acidose, koma og kramper, nyrepåvirkning og kraftig økt aniongap (fig 1) (9). Osmolalt gap kan være normalt. Utregning av aniongap gjøres noe ulikt, men en enkel formel er resultatet av «natrium minus klor minus bikarbonat».

Aniongapet, som er summen av negative ladninger, blant annet fosfat, sulfat og serumproteiner, som vanligvis ikke måles, er normalt $12 \pm 4 \mathrm{mmol} / 1$. Etylenglykolforgiftning gir vanligvis en acidose med et betydelig forhøyet aniongap, uten økt klornivå (4). Andre typer metabolsk acidose kan ha normalt aniongap, og oftest er klornivået da betydelig forhøyet.

Selv om aniongapet var forhøyet med 5-8 mmol/l, hadde vår pasient også en hyperkloremisk acidose med et klornivå på $127 \mathrm{mmol} / 1$ (97-107 mmol/l), altså minst 20 mmol forhøyet. Dette skapte forvirring i diagnostikken, da tap av bikarbonat typisk finner sted ved diaré, type 2 renal tubulær acidose og pancreasfistler (13). Hyperkloremisk acidose kan også være forårsaket av infusjon med $0,9 \% \mathrm{NaCl}$, som inneholder 1,5 ganger normalt serumnivå av klor (3). Vår pasient fikk flere liter krystalloider for à kompensere for den store diuresen det første døgnet, men da ble det angivelig brukt Ringers løsning, med tilnærmet fysiologisk klorkonsentrasjon.

Selv om etylenglykolforgiftning vanligvis gir økt aniongap, er det imidlertid beskrevet flere tilfeller der det har vært normalt aniongap uten at man har noen sikker forklaring på hvorfor (14). I flere av disse tilfellene var det også en hyperkloremisk acidose. Mekanismene bak dette antas å være en forbigående hyperkloremi ved raskt innsettende nyresvikt hos pasienter med normal nyrefunksjon (14). Ved normal nyrefunksjon, normovolemi og samtidig stor diurese kan nyrene over enn viss tid klare å holde tilbake klor samtidig som oksalsyre skilles ut. Dermed holdes aniongapet relativt lavt i starten. Ved hypovolemi eller redusert nyrefunksjon, derimot, vil akutt nyresvikt inntre raskere. Nyrenes evne til å retinere klor vil da reduseres, og man vil da se utvikling av aniongap på et tidligere tidspunkt.

Høye doser av etylenglykol kan ha en direkte toksisk effekt på sentralnervesystemet og gi redusert bevissthet, nystagmus, oftalmoplegi, nakkestivhet, ataksi, hypotoni, hyporefleksi, myoklonier og papillødem (15). I tillegg dannes oksalatkrystaller, som deponeres i sentralnervesystemet og kan gi hjerneødem, kramper og koma (16). Danning av oksalatkrystaller kan også gi symptomatisk hypokalsemi. Hjernenerveutfall og polynevropati kan opptre opptil 1-3 uker etter intoksikasjonen (17).

MR cerebrum kan vise forandringer i frontallapp, basalganglier, thalamus, amygdala, hippocampus og hjernestamme (7), noe som passer med funnene hos vår pasient. Det er beskrevet at disse forandringene inntreffer 24-48 timer etter intoksikasjonen og at de kan gå i regress etter 5-35 døgn (7).

I urinprøven tatt første døgn på intensivavdelingen ble det funnet oksalatkrystaller.
Slike krystaller kan ses ved flere tilstander (18). Funn av oksalatkrystaller i urinen sammenholdt med metabolsk acidose og samtidig osmolalt gap og aniongap styrker mistanken om etylenglykolforgiftning og er en indikasjon for behandling med antidot $(5,9)$. Hos vår pasient ble prøven dessverre ikke analysert før fjerde døgn, like før diagnosen ble bekreftet ved blodprøver.

Pasienten hadde en overraskende høy laktatverdi på $29 \mathrm{mmol} / 1$ målt på intensivavdelingens blodgassapparat. Kontrollmålinger av serumprøver fra samme prøvetidspunkt på nedkjølt fluoridglass målt på sentrallaboratoriets apparat viste imidlertid 9,2 $\mathrm{mmol} / \mathrm{l}$.

De første høye laktatverdiene ble tolket som feilmålinger, men senere fikk vi vite at diskrepansen skyldes strukturell likhet mellom laktat og glykolsyre. Noen blodgassapparater (som Radiometer ABL 800) feiltolker altså glykolsyre som laktat (19). Denne måleforskjellen - kalt laktatgap - har vi i ettertid brukt bevisst, i påvente av etylenglykolanalyser ved mistanke om etylenglykolforgiftning, og bruken av laktatgap er tidligere beskrevet som diagnostisk hjelpemiddel $(8,19-21)$.

Feilmålingen av glykolsyre som laktat er imidlertid både avhengig av analysemetoden og av at nok glykolsyre har fått tid til å dannes. Måleteknikken varierer fra produsent til produsent, derfor skjer denne feilmålingen ikke i alle blodgassapparater $(19,22)$. Figur 2 viser diskrepansen i laktatmålingene hos vår pasient. Dessuten kan moderate og sant forhøyede laktatverdier ved etylenglykolforgiftning også forekomme (8).

Ved mistenkt etylenglykolforgiftning må behandlingen startes raskt. I Norge er fomepizol førstevalg i de fleste tilfeller, med unntak av hos gravide $(9,23)$. I påvente av fomepizol kan etanol gis oralt eller intravenøst. Etanol er billig og lett tilgjengelig og er førstevalget ved flere danske sykehus (24). Hemodialyse vurderes ved nyresvikt og $\mathrm{pH}$ $<7,3-7,25$ for å eliminere resterende etylenglykol og glykolsyre (9-12).

\section{Konklusjon}

Vår pasient var en diagnostisk utfordring, men det viste seg til slutt at han hadde en etylenglykolintoksikasjon. Han gjennomgikk en fulminant intoksikasjon med kun støttende behandling. Kasuistikken viser at ved uklart sykdomsbilde og cerebral påvirkning bør det tas blodgass i akuttmottaket. Etylenglykolintoksikasjon gir klassisk en aniongapacidose, men kan i særtilfeller gi en ikke-aniongapacidose.

I påvente av glykolsyreanalyse i blod, som tar tid, kan sykehistorien, metabolsk acidose med økt aniongap, osmolalt gap, laktatgap og oksalatkrystaller i urinen styrke mistanken om etylenglykolforgiftning. Falskt forhøyet 
laktatnivå ved etylenglykolintoksikasjon på noen blodgassapparater er lite kjent, men raskt å påvise, og det kan vise seg svært nyttig $(19,20)$.

Pasienten har gitt samtykke til at artikkelen blir publisert.

Vi takker Knut Erik Hovda, Dag Jacobsen, Ole Lars Brekke, Søren Jacob Bakke og Olav Spigset for gode kliniske råd under diagnostikk og behandling.

\section{Magnus Salomonsen (f. 1982)}

er lege i spesialisering ved Akuttmedisinsk klinikk. Han samlet anamnese og kliniske funn ved gjennomgang av journal og behandlet pasienten. Han har deltatt aktivt i utformingen av artikkelen både med faglige tilbakemeldinger og behandling av tekst.

Forfatter har fylt ut ICMJE-skjemaet og oppgir ingen interessekonflikter.

\section{Randolf Hardersen (f. 1967)}

er spesialist i indremedisin og nefrologi og avdelingsoverlege. Han behandlet pasienten, har deltatt aktivt i utformingen av artikkelen og har gjennomgått den flere ganger før innsending ut fra en nyremedisinsk synsvinkel. Forfatter har fylt ut ICMJE-skjemaet og oppgir ingen interessekonflikter.

\section{Maria Carlsson (f. 1971)}

er spesialist i nevrologi og overlege. Hun behandlet pasienten, har deltatt aktivt i utformingen av artikkelen og har gjennomgått den flere ganger før innsending ut fra en nevrologisk synsvinkel.

Forfatter har fylt ut ICMJE-skjemaet og oppgir ingen interessekonflikter.

\section{Erik Waage Nielsen (f. 1956)}

er overlege og professor og har europeisk intensiveksamen (EDIC 1 \& 2). Han behandlet pasienten og har som veileder for artikkelen deltatt aktivt i utformingen av den, både med faglige tilbakemeldinger og behandling av tekst, og har gjennomgått manus flere ganger Forfatter har fylt ut ICMJE-skjemaet og oppgir ingen interessekonflikter.

\section{Litteratur}

1. Kraut JA, Madias NE. Metabolic acidosis: pathophysiology, diagnosis and management. Nat Rev Nephrol 2010; 6: 274-85

2. Giftinformasjonen. Sopp, amatoksin (hvit fluesopp, grønn fluesopp og flatklokkehatt) - behandlingsanbefaling ved forgiftning. 30.6.2011 www.helsebiblioteket.no/forgiftninger/sopp/ sopp-amatoksin-hvit-fluesopp-gr\%C3\%B8nnfluesopp-og-flatklokkehatt-behandlingsanbefalingved-forgiftning\#SymptomerOgKliniskeTegn. (21.12.2012)

3. Reid F, Lobo DN, Williams RN et al. (Ab)normal saline and physiological Hartmann's solution: a randomized double-blind crossover study. Clin Sci (Lond) 2003: 104: 17-24.

4. Hovda KE, Hunderi OH, Øvrebø S et al. Utredning av metabolsk acidose av ukjent årsak. Tidsskr Nor Lægeforen 2004; 124: 3203-5.

5. Nymark TB, Soløy-Nilsen H, Steen R et al. Vekttap og akutte magesmerter hos en 38 år gammel stoffmisbruker. Tidsskr Nor Lægeforen 2007; 127: 299-300

6. Nevro-NEL. Posterior reversibelt leukoencefalopati syndrom PRES. 17.11.2012. http://nevro. legehandboka.no/cerebrovaskulere-sykdommer/ posterior-reversibelt-encefalopati-syndrom-pres 33585.html (17.6.2013).

7. Geibprasert S, Gallucci M, Krings T. Alcoholinduced changes in the brain as assessed by MRI and CT. Eur Radiol 2010; 20: 1492-501.

8. Porter WH. Ethylene glycol poisoning: quintessential clinical toxicology; analytical conundrum. Clin Chim Acta 2012: 413: 365-77.

9. Giftinformasjonen. Etylenglykol - behandlingsanbefaling ved forgiftning. Utfyllende informasjon. 21.7.2011. www. helsebiblioteket.no/forgiftninger/ gasser-og-kjemikalier/etylenglykolbehandlingsanbefaling-ved-forgiftning. utfyllende-informasjon (5.5.2013)

10. Velez LI, Shepherd G, Lee YC et al. Ethylene glyco ingestion treated only with fomepizole. J Med Toxicol 2007: 3: 125-8.

11. Scalley RD, Ferguson DR, Piccaro JC et al. Treatment of ethylene glycol poisoning. Am Fam Physician 2002; 66: 807-12

12. Barceloux DG, Krenzelok EP, Olson Ket al. American Academy of Clinical Toxicology Practice

Guidelines on the Treatment of Ethylene Glycol

Poisoning. J Toxicol Clin Toxicol 1999; 37: 537-60.
13. Post TW. Approach to the adult with metabolic acidosis. UpToDate versjon. 6.10.2010. www uptodate.com/contents/approach-to-theadult-with-metabolic-acidosis?source=search result\&search=metabolic+acidosis\&selected Title $=1 \% 7 E 150$ (21.12.2012)

14. Soghoian S, Sinert R, Wiener SW et al. Ethylene glycol toxicity presenting with non-anion gap metabolic acidosis. Basic Clin Pharmacol Toxicol 2009; 104: 22-6.

15. Hess R, Bartels MJ, Pottenger LH. Ethylene glycol: an estimate of tolerable levels of exposure based on a review of animal and human data. Arch Toxicol 2004; 78: 671-80

16. Jammalamadaka D, Raissi S. Ethylene glycol, methanol and isopropyl alcohol intoxication. Am J Med Sci 2010: 339: 276-81

17. Zhou L, Zabad R, Lewis RA. Ethylene glycol intoxication: electrophysiological studies suggest a polyradiculopathy. Neurology 2002; 59: 1809-10.

18. Alkhunaizi AM, Chan L. Secondary oxalosis: a cause of delayed recovery of renal function in the setting of acute renal failure. J Am Soc Nephrol 1996; 7: 2320-6.

19. Meng QH, Adeli K, Zello GA et al. Elevated lactate in ethylene glycol poisoning: true or false? Clin Chim Acta 2010; 411: 601-4

20. Höjer J, Persson H, Personne M. Falskt förhöjda laktatvärden kan avslöja etylenglykolförgiftning. Läkartidningen 2008; 105: 438-40.

21. Woo MY, Greenway DC, Nadler SP et al. Artifactual elevation of lactate in ethylene glycol poisoning J Emerg Med 2003; 25: 289-93.

22. Morgan TJ, Clark C, Clague A. Artifactual elevation of measured plasma L-lactate concentration in the presence of glycolate. Crit Care Med 1999; 27 2177-9.

23. Fomepizole «EUSA Pharma». www.felleskatalogen.no/medisin/ fomepizole-eusa-pharma-559316 (5.5.2013).

24. Etylenglykolforgiftning. www.sundhed.dk/ sundhedsfaglig/laegehaandbogen/akut-ogfoerstehjaelp/tilstande-og-sygdomme/ forgiftninger/etylenglykolforgiftning/ (5.5.2013).

Mottatt 10.2. 2013, første revisjon innsendt 13.5. 2013, godkjent 6.10. 2013. Redaktør: Merete Kile Holtermann.

\section{Kommentar}

\section{Metabolsk acidose - ikke alltid like lett}

Denne gode kasuistikken fra Salomonsen og medarbeidere illustrerer at det kan være vanskelig å finne årsaken til akutt metabolsk acidose. De vanligste årsakene er ketoacidose og laktacidose (1). Den første vil ofte skyldes diabetisk ketoacidose, med tilhørende klinisk presentasjon, mens laktacidose kan ses i forbindelse med ulike årsaker til hypoperfusjon.
Metabolsk acidose kan også oppstå i forbindelse med inntak av metanol eller etylenglykol. Inntak av selv små mengder kan være letalt, og slike forgiftninger fører jevnlig til dødsfall i Norge. Det kan være direkte livreddende å avdekke årsaken raskt, ikke minst fordi det finnes en effektiv antidot (fomepizol) som kan brukes ved både metanol- og etylenglykolforgiftning (2). Direkte måling av metanol eller etylenglykol utføres ved de færreste sykehuslaboratorier i Norge, så den initiale behandlingen må bygge på klinisk presentasjon og laboratoriefunn.

De første symptomene på forgiftning med metanol eller etylenglykol er vanligvis uspesifikke og skyldes blant annet sentralnervøs påvirkning fra «modersubstansen» - ikke ulikt vanlig etanolpåvirkning. Gradvis, etter 